\title{
REGIONÁLNÍ HODNOCENÍ KVALITY SOCIÁLNÍHO PROSTŘEDÍ - PŘÍPADOVÁ STUDIE ČESKÉ REPUBLIKY
}

\section{REGIONAL EVALUATION OF SOCIAL ENVIRONMENT QUALITY - A CASE STUDY OF THE CZECH REPUBLIC}

\author{
DOC. RNDR. MILAN VITURKA, CSC. \\ Katedra regionální ekonomie a správy $\mid$ Depart. of Regional Economics and Administration \\ Ekonomicko-správni fakulta Faculty of Economics and Administration \\ Masarykova univerzita Masaryk University \\ $\triangle$ Lipová 41 a, 60200 Brno, Czech Republic \\ E-mail:viturka@econ.muni.cz
}

\begin{abstract}
Anotace
Cílem článku je představit výsledky hodnoceni kvality sociálniho prostředí (KSP) za mikroregiony (územni obvody obci s rozšírenou puisobností 3. stupně - regiony ORP) a mezoregiony (kraje regiony NUTS 3) České republiky. Originální metoda hodnoceni je založena na vybraných faktorech interpretujicich kličové oblasti sociálního prostředi (sociální, demografickou, urbanistickou, infrastrukturni a environmentálni). Na tomto základě byly regiony ORP rozděleny do tř́ skupin: progresivni, standardni a regresivni regiony. Krajské hodnoty pak byly ziskány agregaci mikroregionálních hodnot vážených př́slušnými počty obyvatel. Pro územní rozloženi hodnot KSP je charakteristická poměrně nizká úroveñ diferenciace a dále byla prokázána tendence k poklesu těchto hodnot směrem khranicim regionů NUTS 3. Celkově lze konstatovat, že špatná KSP snižuje residenčni i investični atraktivitu regionů a tedy i dlouhodobou udržitelnost jejich rozvoje.
\end{abstract}

\section{Kličová slova}

regionální rozvoj, sociální prostředí, typologie.

\section{Annotation}

The aim of the article is to present the results of evaluation concerning of social environment quality (SEQ) according to micro-regions (territorial districts of municipalities with extended competencies of 3rd degree - MEC regions) and mezo-regions (kraje - regions NUTS 3) of the Czech Republic. The original method of evaluation is based on the selected factors representing key areas of SEQ (social, demographic, urban, infrastructure and environmental area). On this basis the MEC regions were divided into three groups: regions with progressive, standard and regressive SEQ. The NUTS 3 values were then obtained by aggregation of micro-regional values weighted by relevant population. It can be stated that territorial distribution of the $S E Q$ values is characterized by relatively low level of differentiation and further a tendency to decreasing of these values towards to the borders of NUTS 3 regions has been also demonstrated. Overall, it can be concluded that poor SEQ reduces residential and investment attractiveness of the regions and hence long-term sustainability of their development.

\section{Key words}

regional development, social environment, typology.

JEL classification: $R 11$

\section{1. Úvodní poznámky}

Společenský rozvoj a jeho pozitivní a negativní konsekvence nepochybně vytvářejí základní rámec pro naplňování poznávací funkce společenských věd. $V$ tomto kontextu je dále pozornost soustředěna 
na sociální rozvoj, který lze spolu s ekonomickým a environmentálním rozvojem pokládat za jeho základní strukturální komponentu. Tento článek se zabývá především prostorovými souvislostmi sociálního rozvoje s důrazem na jeho úroveň, která je hodnocena na základě regionální kvality sociálního prostředí (KSP).

$\mathrm{V}$ tomto ohledu považujeme za inspirativní koncept hodnocení kvality života, který se rozvinul ve druhé polovině minulého století. Postupně se vytvořily tři základní výzkumné směry hodnocení kvality života. První z nich je možné označit jako normativní. Podstatou tohoto sociologického směru je aplikace tzv. objektivních sociálních indikátorů odrážejících idealizované představy o žádoucím společenském rozvoji (objective well-being). Druhý směr definující kvalitu života na základě míry uspokojování spotřebitelských preferencí obyvatel lze označit jako ekonomický. Jde o zjevně redukcionistický směr, nebot' kvalita života je nepochybně významně ovlivňována i faktory stojícími mimo ekonomiku (např. demografické faktory, kvalita lidských vztahů či úroveň občanských svobod). Poslední př́stup se označuje jako psychologický, nebot' definuje kvalitu života na základě subjektivních představ obyvatel formovaných jejich životním uspokojením a zohledňujícím výskyt př́jemných a nepř́jemných ovlivňujících faktorů (subjective well-being). Tyto představy prrirozeně nemusí korespondovat s objektivními sociálními a ekonomickými indikátory. Celkově lze konstatovat, že dosud neexistuje jasná shoda ani o definici, ani o metodách měření kvality života.

Rostoucí popularita hodnocení kvality života významně souvisí s dlouhodobě probíhajícími diskusemi o dominantní roli HDP jako hlavního měřítka společenského rozvoje. Mezi základní otázky zde nepochybně patř́ problematické používání vývoje HDP pro predikci dlouhodobého rozvoje jednotlivých zemí. Tato praxe vyvolala řadu iniciativ, ze kterých lze uvést zejména koncept čistého ekonomického blahobytu - net economic welfare (předpokládající takovou úpravu HDP, aby odrážel pouze položky přispívající k ekonomickému blahobytu tj. ostatní položky, např. škody na životním prostředí, jsou odpočítávány) a iniciativu OSN cílenou na doplnění tokové veličiny HDP stavovou veličinou měřící celkové bohatství národů (vykazující všestrannější vazby na budoucí rozvoj). Dalším důvodem je faktické redukování společenského rozvoje pouze na jeho ekonomickou komponentu (jako často uváděný př́klad snahy o zavedení komplexnější míry společenského rozvoje lze uvést tzv. index hrubého národního štěstí, zavedený v Bhútánu). Uvedené aktivity lze nepochybně chápat i jako významný př́spěvek $\mathrm{k}$ vytváření potřebných předpokladů pro účinnější uplatňování konceptu udržitelného rozvoje, obecně interpretovaného jako takový způsob rozvoje, který uspokojuje potřeby přítomnosti, aniž by oslaboval možnosti naplňování potřeb budoucích generací (Bruntland, 1987).

Na rozpracování konceptu kvality života se podílela řada autorů, mezi které patří např. Diener, Suh (1997), Rogerson, Findlay, Morris (1989), Smith (1973), Veenhoven (1996), Andráško (2008) a Ira (2008). V rámci užitých přístupů $\mathrm{k}$ hodnocení kvality života se s největším zájmem veřejnosti setkaly Human development index (HDI) publikovaný každoročně UNDP, Economist Intelligence unit's index a Mercer's quality of living report a dále žebrríčky kvality života měst resp. metropolitních regionů, jejichž významným popularizátorem je známý ekonomický časopis Fortune. Z institucí věnujících se hodnocení kvality života lze dále uvést OECD (Better life initiative), European union (Eurobarometer), World bank (World development indicators) a World resources institute (World resources). $Z$ domácích autorů se pak hodnocením kvality života zabývali zejména Kreidl, Nováček a Mederly (2004), kteří sestavili index kvality a udržitelnosti života jako alternativu k HDI - poslední dva uvedení autoři se v rámci Centra pro sociální a ekonomické strategie Univerzity Karlovy kvalitě života věnovali i na regionální úrovni. Na pozadí tzv. faktorové ekologie měst se pak danou problematikou zabývali např. Matějů (1980)], Vystoupil (1987), Toušek (1997), Kladivo (2011) a Živělová (2009). Potřebné je zmínit i Wokouna (2011), který vedl zpracování studie MasterCard zaměřené na hodnocení sociální situace 63 nejvýznamnějších českých a moravských měst pomocí 12 ukazatelů zahrnujících 5 oblastí - trh práce, cenu bydlení, kvalitu sociální a zdravotní péče, kriminalitu a prrijmy obyvatelstva. 


\section{Cíl a metodika výzkumu}

Hlavním cílem provedeného výzkumu je vyhodnocení kvality sociálního prostředí na mikroregionální a mezoregionální úrovni České republiky. Jako jednotky pro mikroregionální hodnocení KSP byly zvoleny územní obvody obcí s rozšířenou působností 3. stupně resp. ORP (dále regiony ORP) celkem 205 jednotek mimo Prahu, které lze ztotožnit s nodálními regiony utvářenými na základě vazeb centra $\mathrm{s}$ jeho zázemím. Mezoregionální úroveň pak tvoří 14 krajů resp. regionů NUTS 3 (dále kraje). Tato úroveň představuje v České republice (spolu s 8 umělými regiony NUTS 2 vytvořenými pro implementaci Kohezní politiky EU) hlavní prostorový rámec regionální politiky.

KSP je chápána jako agregátní výsledek různorodých procesů a vlivů formujících základní podmínky sociálního rozvoje regionů. Její hodnocení je komplikované již samotnou pluralitou př́stupů k chápání ústředního pojmu kvality života. Pro náś účel se jako nejvhodnější jeví aplikace tzv. objektivních sociálních indikátorů. Zde je však nutné upozornit na neexistenci všeobecně akceptovatelné metody výběru těchto indikátorů resp. faktorů při neexistenci všeobecného indikátoru srovnatelného s HDP. Jejich výběr je proto do značné míry individuální záležitostí, odrážející nejen odborné znalosti a preference zpracovatele, ale i dostupnost relevantních ukazatelů. Často diskutovaným problémem jsou i váhy vybraných faktorů. $\mathrm{V}$ tomto ohledu se kloníme k názoru, že jejich zavedení by nebylo účelné, nebot' ,ideální“ společenský rozvoj by měl reflektovat preference všech skupin obyvatelstva, aniž by některé z nich byly upřednostněny před preferencemi jiných skupin (např. indikátory nezaměstnanosti jsou zcela relevantní jen pro obyvatelstvo v produktivním věku). Zavedení vah je navíc spojeno s rizikem zkreslování výsledků hodnocení - pro ilustraci lze uvést americkou studii (Becker et al. 1987), kde při použití různých vah byla pětina zkoumaných metropolitních areálů USA zařazena bud' do nejlepší, nebo naopak do nejhorší skupiny.

Po provedených analýzách bylo pro hodnocení KSP vybráno celkem 16 faktorů, ze kterých byla většina podrobena důkladné statistické analýze již v rámci dřívějších studií (Kunc, Synková, 2010, Kutscherauer, 2010, Mederly et al., 2004). Prezentované pojetí je založeno na vícerozměrném hodnocení KSP a v souladu s tím byla značná pozornost věnována klíčovým oblastem hodnocení, identifikovaných s využitím předchozích výzkumů. Tyto oblasti pak byly popsány pomocí vybraných faktorů, které mají z pohledu jednotlivých aktérů regionálního rozvoje (občané, podnikatelé, veřejná správa) exogenní charakter a lze je rozdělit do pěti skupin:

- sociální faktory - naděje dožití, vzdělanost, nezaměstnanost, rozvodovost, potratovost, kriminalita

- demografické faktory - přirozený pohyb obyvatelstva, mechanický pohyb obyvatelstva, věková struktura obyvatelstva

- urbanistické faktory - urbanizace, urbanistický rozvoj, urbanistické prostředí

- infrastrukturní faktory - zdravotnická infrastruktura, sociální infrastruktura

- environmentální faktory - krajinná struktura, kvalita ovzduší.

KSP jednotlivých regionů ORP pak představuje součty hodnot dílčích faktorů, které byly získány následujícím postupem: zařazení regionů podle hodnot primárních ukazatelů relevantních pro jednotlivé faktory s využitím statistických skupin vytvořených na základě analýzy rozložení, finální zařazení regionů podle dílčích faktorů a transformace výsledků parciálních hodnocení do generalizovaných stupňů užitých pro komplexní hodnocení (od nejlepšího 1. stupně po nejhorší 5 . stupeň). Krajské hodnoty pak byly získány agregací vypočtených mikroregionálních hodnot vážených př́slušnými počty obyvatel. Ze širšího pohledu lze konstatovat, že KSP je významně spjata s kvalitou podnikatelského prostředí (KPP), která představuje primární spojovací článek s teritoriálně chápanou konkurenceschopností, kterou lze obecně definovat jako schopnost regionů generovat relativně vysoké př́jmy a úroveň zaměstnanosti v podmínkách jejich vystavení vnější konkurenci (European Commission, 1999). Tuto definici je možné z dlouhodobého pohledu interpretovat tak, že základem konkurenceschopnosti je vysoká atraktivita regionů pro podnikání a pro bydlení. Z této interpretace pak lze vyvozovat, že regionální konkurenceschopnost je ovlivňována nejen úrovní podnikatelského prostředí [podrobněji Viturka a kol., 2011, Viturka, 2011), ale i úrovní KSP přičemž její dlouhodobá 
udržitelnost je podmíněna vyváženým vztahem obou komponent. $Z$ individuálního pohledu pak jde v podstatě o řešení jedné ze základních existencionalistických otázek, a sice jak a kde žít.

\section{Hlavní výsledky výzkumu}

Hodnocení KSP poskytuje veřejné správě, podnikatelské sfeěre a dalším uživatelům územně a věcně strukturované informace o relevantních faktorech ovlivňujících kvalitu života obyvatel České republiky, které mají adekvátní dopady na celospolečenskou efektivnost stávajícího modelu ekonomického rozvoje (trvalé zhoršování kvality života, vyvolané např. rostoucími škodami na životním prostředí či výrazným zvyšováním kriminality nepochybně přispívá ke zvyšování „neproduktivních“ nákladů jak veřejného, tak i soukromého sektoru). Na základě výše definované soustavy faktorů byla v první etapě vyhodnocena KSP za regiony ORP. Podle její úrovně lze tyto regiony rozdělit na progresivní (regiony se silně nadprůměrnou úrovní KSP tj. s úhrnnými hodnotami nižšími než 2,5 - vzhledem $\mathrm{k}$ dalším výhodám, týkajícím se např. nabídky kulturních aktivit, sem byly dodatečně zařazeny i regiony krajských měst s hodnotami KSP mírně převyšujícími uvedenou hranici), standardní (regiony s průměrnou úrovní KSP) a regresivní (regiony se silně podprůměrnou úrovní KSP tj. s úhrnnými hodnotami vyššími než 3,5). Z výsledků hodnocení vyplývá, že pro územní rozložení hodnot KSP je charakteristická poměrně nízká úroveň diferenciace (nejsou zastoupeny obě krajní klasifikační skupiny a přibližně $3 / 4$ regionů spadá do průměrné skupiny). Dalším významným rozdílem je skutečnost, že na rozdíl od KPP ne všechny póly rozvoje, představované regiony krajských měst včetně Prahy doplněné regionem M. Boleslavi, disponují nadprůměrnou hodnotou výjimku představují regiony K. Var, Ústí n. L. a Ostravy, které jako póly rozvoje strukturálně nejvíce postižených krajů vykazují pouze průměrnou KSP (toto zjištění je možné chápat i jako empirické potvrzení Myrdalovy teorie oběžné kumulativní kauzality). Kromě většiny pólů rozvoje (nejlepší hodnoty KSP se však nevztahují $\mathrm{k}$ Praze, ale $\mathrm{k}$ Č. Budějovicím a Pardubicím) disponuje nadprůměrnou KSP ještě osm dalších regionů. Tyto regiony se nacházejí především ve Středočeském a Jihomoravském kraji (zázemí Prahy a Brna) a dále v krajích Pardubickém, Vysočina a Jihočeském. Ostatní regiony jsou pak $\mathrm{v}$ dominantním podílu zařazeny do průměrné (156 regionů) a dále do podprůměrné (31 regionů) skupiny. Průměrné hodnoty KSP podle statisticky optimalizovaných velikostních skupin regionů s hraničními hodnotami 180, 90, 45 a 18 tis. obyvatel pak činí 2,78; 2,87; 3,$03 ; 3,12$ a 3,19 .

Z rozvojového pohledu hrají hlavní roli faktory determinující silné a slabé stránky regionální KSP. V př́ipadě první velikostní skupiny (tvořené regiony největších měst tj. Prahy, Brna, Plzně a Ostravy) tak představují silnou stránku především faktory urbanizace, zdravotnické infrastruktury, naděje dožití a vzdělanosti, a naopak slabou stránku faktory kriminality, věkové struktury obyvatelstva, krajinné struktury a kvality ovzduší. Velmi podobné rysy v tomto směru vykazuje i druhá velikostní skupina (celkem 18 regionů), která se od předchozí skupiny liší pouze rozš́iřením silných stránek o faktor nezaměstnanosti a faktor urbanistického rozvoje (tento rozdíl je významně podmíněn specifickým územním vymezením nejvýznamnějších městských regionů a dále zařazením Ostravy do první skupiny). Následující dvě velikostní skupiny se ve srovnání s nadprůměrnými skupinami vyznačují výrazně vyšší mírou heterogenity. V rámci třetí skupiny (47 regionů) tak byly jako silné stránky identifikovány pouze faktor vzdělanosti a faktor zdravotnické infrastruktury a jako slabá stránka faktor kriminality a v př́padě nejsilněji zastoupené čtvrté skupiny (101 regionů) lze již jako významný identifikovat pouze faktor urbanistického prostředí, představující slabou stránku př́íslušných regionů. U páté skupiny (36 regionů) však dochází k opětovnému nárůstu homogenity, kdy její silnou stránku tvoří (poněkud přkvapivě) faktor nezaměstnanosti a faktor kvality ovzduší a slabou stránku pak všechny urbanistické faktory a dále faktory vzdělanosti a zdravotnické a sociální infrastruktury. $Z$ výše uvedených informací lze dále vyvozovat, že na úrovni regionů ORP hrají nejméně významnou diferenciační roli faktory rozvodovosti a potratovosti a dále faktory přirozeného a mechanického pohybu obyvatelstva (v tomto kontextu bylo v rámci vymezených skupin identifikováno celkem 56 regionů s příznivou úrovní základních demografických faktorů). Vývojová diferenciace hodnot těchto faktorů je tedy rozhodujícím způsobem determinována procesy vznikajícími na vyšších hierarchických úrovních (např̀. všeobecné změny životního stylu obyvatelstva či liberalizace př́slušné národní legislativy). 
Ve druhé etapě byly provedeny agregace mikroregionálních hodnot KSP podle českých krajů (viz tabulka). Z těchto agregací vyplývá, že vážené krajské hodnoty KSP se pohybují v nepř́iliš velkém rozpětí od +18 do $-15 \%$ (resp. od +15 do $-12 \%$ bez Pražského kraje) kolem odpovídajícího průměru. Ve dvou strukturálně postižených krajích Moravskoslezském a Karlovarském je KSP krajského města dokonce horší než agregovaná hodnota za celý kraj. Pokud pak jde o vztah KSP a HDP byla zjišstěna pouze slabá závislost. Obecnou př́činou této skutečnosti jsou, kromě toho že HDP nezohledňuje hodnoty vznikající mimo ekonomiku (např. jedinečnost krajinné struktury), již samotné základní rozdíly $\mathrm{v}$ dlouhodobé dynamice procesů sociální a ekonomické reprodukce, zejména postupné prodlužování reprodukčních cyklů tj. obměny obyvatelstva $\mathrm{v}$ prvním př́ípadě a naopak postupné zkracování reprodukčních cyklu tj. obměny produktů a technologií ve druhém př́padě, s adekvátními vlivy na vývoj sociálního prostředí. Specifickou prríčinou je protikladné působení řady faktorů, které lze nejlépe demonstrovat na př́kladu skupiny environmentálních (nejlepšími hodnotami disponují venkovské regiony) a skupiny urbanistických (nejlepšími hodnotami disponují městské regiony) faktorů.

Tab. 1: Celkové hodnoty KSP podle krajů

\begin{tabular}{|l|c|c|c|}
\hline kraj & KSP & KSP centra & počet obyv. v tis. \\
\hline Praha & 2,50 & $\mathrm{x}$ & 1273 \\
\hline Středočeský & 2,90 & 2,44 & 1275 \\
\hline Jihočeský & 2,64 & 2,31 & 637 \\
\hline Plzeňský & 2,91 & 2,56 & 575 \\
\hline Karlovarský & 3,31 & 3,38 & 310 \\
\hline Ústecký & 3,47 & 3,09 & 830 \\
\hline Liberecký & 2,93 & 2,53 & 439 \\
\hline Královéhradecký & 2,87 & 2,56 & 556 \\
\hline Pardubický & 2,74 & 2,31 & 518 \\
\hline Vysočina & 2,73 & 2,44 & 513 \\
\hline Jihomoravský & 2,93 & 2,56 & 1170 \\
\hline Olomoucký & 3,03 & 2,50 & 640 \\
\hline Zlínský & 2,89 & 2,50 & 590 \\
\hline Moravskoslezský & 3,40 & 3,50 & 1236 \\
\hline Česká republika & $\mathbf{2 , 9 5}$ & $\mathbf{2 , 5 0}$ & $\mathbf{1 0 5 6 2}$ \\
\hline
\end{tabular}

Poznámka: V př́ípadě Středočeského kraje je údaj pro KSP centra vztažen k regionu Mladé Boleslavi.

Zdroj: vlastní výzkum, ČSÚ (census 2011).

Na základě syntézy získaných výsledků byly v prostorovém rozložení hodnot KSP zjištěny následující pravidelností resp. tendence:

- mezoregionální úroveň - převládající tendence ke zhoršování mikroregionálních hodnot KSP směrem $\mathrm{k}$ hranicím krajů $\mathrm{v}$ souladu $\mathrm{s}$ teoriemi skupiny jádro - periférie (selektivně modifikované jejich dosavadním sociálním vývojem a vývojem př́slušných krajských center)

- makroregionální úroveň - žádná jasně převládající tendence nebyla identifikována, tato úroveň je však úzce spojena s významnými negativními anomáliemi KSP (indukovanými nadměrnou preferencí strategicky významných odvětví těžebního, energetického a těžkého průmyslu v období centrálně plánované ekonomiky).

Výše uvedené skutečnosti potvrzují nezpochybnitelný význam nižších hierarchických úrovní (zejména regionů ORP) v procesech formování sociálního prostředí a dále značnou setrvačnost negativních regionálních vývojových trendů nastolených $\mathrm{v}$ uplynulých obdobích. Z hlediska celkového společenského rozvoje je potřebné připomenout $\mathrm{v}$ ekonomické teorii poměrně často opomíjenou skutečnost, že KSP významným způsobem ovlivňuje dlouhodobou konkurenceschopnost a udržitelnost rozvoje jednotlivých zemí a jejich regionů. Tento logický závěr koresponduje se zjištěním, že kraje s podprůměrnou úrovní KSP zaznamenaly v mezidobí obou posledních sčítání lidu 
tj. 2001 až 2011 stagnaci příp. úbytek počtu obyvatel - vůbec nejvyšší populační pokles o 2,5 \% byl v tomto ohledu zjištěn v Moravskoslezském kraji (pro srovnání celá Česká republika zaznamenala př́růstek o 3,2 \%). Uvedený proces je úzce spojen s nadprůměrnou emigrací obyvatelstva, která je koncentrovanou především na mladší a vzdělanější skupiny což logicky oslabuje budoucí konkurenceschopnost př́slušných krajů.

\section{Závěr}

Prezentovaný př́spěvek poskytuje teoreticky i prakticky významné informace o kvalitě sociálního prostředí za mikroregiony a mezoregiony České republiky, které do určité míry integrující ekonomické a sociologické př́stupy $\mathrm{k}$ výzkumu kvality života. Dosažený výsledky představují užitečnou generalizaci složité skutečnosti, která přispívá nejen k probíhajícímu vědeckému diskurzu, ale i k praktickému řešení základních problémů spojených s efektivním a udržitelným společenským rozvojem. Konceptualizace získaných poznatků v rámci regionální politiky (v systémové vazbě na optimalizaci strategických priorit hospodářské a sociální politiky) je však komplikována celou řadou problémů spojených již se samotnou definicí, neexistující ucelenou teorií a praktickou aplikací pojmu udržitelný rozvoj včetně jeho vazeb na rovněž nedostatečně vyjasněný koncept teritoriální konkurenceschopnosti a kvality života. Chápání uvedených pojmů je navíc nutně determinováno všeobecnou hodnotovou orientací společnosti, posuzované $\mathrm{v}$ našem př́padě v rámci tzv. euroatlantického kulturního okruhu - v této souvislosti se ztotožňujeme s názorem, že idea o univerzální hierarchii potřeb není dostatečně podložena [13]. Vytvoření univerzální a nezpochybnitelné teorie udržitelného rozvoje $\mathrm{v}$ duchu kritického racionalizmu K. Poppera proto považujeme (přinejmenším v blízké budoucnosti) za málo pravděpodobné. Tyto gnozeologické problémy by však neměly sloužit jako záminka pro zpochybňování praktické potřeby řešení dané problematiky v širokém kontextu sociálních a pochopitelně i ekonomických a environmentálních souvislostí.

\section{Literatura}

[1] ANDRÁŠKKO, I. Kvalita života ako súčast' profilu konkurencieschopného regiónu? In Klímová, V. (ed.) XI. mezinárodní kolokvium o regionálních vědách. Sborník př́spěvkủ. Brno: Masarykova univerzita, 2008. s. 39-44.

[2] BECKER, R., DENBY, L., MCGILL, R, WILKS, A. Analysis of data from the Places Rated Almanac. The American Statistician, 1987, č. 41, s. 169-186.

[3] BRUNTLAND, G. Our common future. Oxford University Press, 1987, 400 s.

[4] DIENER, E., SUH, E. Measuring quality of life: economic, social and subjective indicators. Social Indicators Research, 1997, č. 40, s. 189-216.

[5] EUROPEAN COMMISSION. Sixth Periodic Report on the Social and Economic Situation and Development of Regions in the European Union. Brussels: European Communities, 1999, $242 \mathrm{s.}$

[6] IRA, V., ANDRÁŚSO, I. Quality of life in the urban environment of Bratislava: two time-spatial perspectives. Geografický časopis, 2008, č. 2, s. 149-178.

[7] KLADIVO, P. Prostorová diferenciace kvality života obyvatel města Olomouc [Disertační práce]. Brno: Masarykova univerzita, 2011. $161 \mathrm{~s}$.

[8] KUNC, J., SYNKOVÁ, L. Brněnská př́iměstská oblast: př́iklad jejího vymezení. In Klímová, V. (ed.) XIII. mezinárodní kolokvium o regionálních vědách. Sborník př́spěvků. Brno: Masarykova univerzita, 2010. s. 284-290.

[9] KUTSCHERAUER, A. Integrované indikátory a modelové regiony pro hodnocení regionálních disparit v České republice. In Klímová, V. XIII. mezinárodni kolokvium o regionálních vědách. Sbornik príspěvkü. Brno: Masarykova univerzita, 2010. s. 17-24.

[10] MATĚJŮ, P. Vývoj sociálně prostorové struktury Prahy v letech 1930 - 1970 ve světle FAKTOROVÉ analýzy. Sociologický časopis, 1980, č. 4, s. 572-591.

[11] MEDERLY, P., NOVÁČEK, P., TOPERCER, J. Indikátory kvality života a udržitelného rozvoje: kvalitativní, vícerozměrný a variantní přistup. Praha: Univerzita Karlova, 2004, 117 s.

[12] ROGERSON, R, FINDLAY, A., MORRIS, A. Indicators of quality of life: some methodological issues. Environment and Planning, 1989, č. 21, s 1655-1666. 
[13] SMELSER, N. The handbook of economic sociology. Princeton University Press, 1994. 835 s.

[14] SMITH, M. The geography of social well-being in the United States: an introduction to territorial social indicators. New York: McGraw Hill, 1973. $144 \mathrm{~s}$.

[15] TOUŠEK, V., KELLNEROVÁ, H. Brno z pohledu faktorové ekologie. Moravian Geographical Report, 1997, č. 1, s. 45-51.

[16] VEENHOVEN, R. Happy life expectancy - A comprehensive measure of quality-of-life in nations. Social Indicators Research, 1996, č. 39, s. 1-58.

[17] VITURKA, M., ŽÍTEK, V., KLÍMOVÁ, V., TONEV, P. Application of Microeconomic and Macroeconomic Approach to Evaluating Disparities in the Regional development. Ekonomický časopis, 59, 7, Bratislava: SAV, 2011, 9, s 71-90.

[18] VITURKA, M. Integrační teorie udržitelného regionálního rozvoje (představení a aplikace). Politická ekonomie, 2011, č. 6, s. 794-809.

[19] VYSTOUPIL, J., WĘCŁAWOWICZ, G. Geografia społeczna miast (zróżnicowanie społecznoprzestrzenne). Warszawa: Wydavnictvo Naukowe PWN, 1987, $161 \mathrm{s.}$

[20] WOKOUN, R., DAMBORSKÝ, M., KOUŘILOVÁ, J. Česká centra rozvoje - výsledky odborné studie. MasterCard Worldwide, 2011, $64 \mathrm{~s}$.

[21] ŽIVĚLOVÁ, I., JÁNSKÝ, J. Vývoj disparit v kvalitě života v okresech Jihomoravského kraje. In Účetnictví a reporting udržitelného rozvoje. Praha: Ministerstvo životního prostředí ČR, 2009, s. $978-986$. 